Дорофєєв М. В. ${ }^{1}$ (ORCID: 0000-0001-8607-2483);

Семененко В. М., к.т.н., с.н.c. ${ }^{2}$ (ORCID: 0000-0001-5774-0868)

1 - Центральний науково-дослідний інститут Збройних Сил України, Київ;

2 - Центр воєнно-стратегічних досліджень Національного університету оборони України імені Івана Черняховського, Київ

\title{
Аналіз методів та систем наведення сучасних артилерійських босприпасів
}

Резюме. У статті здійснено аналіз методів та систем наведення сучасних високоточних артилерійських боєприпасів і варіанти їх реалізації в артилерійських системах провідних у військовому відношенні армій світу.

Ключові слова: методи наведення; артилерійські снаряди; GPS; радіонавігаційні космічні системи.

Постановка проблеми. 3 огляду на досвід ведення бойових дій на Сході України, досягнення необхідного ефекту ураження цілей під час стрільби артилерійськими системами потребує значної витрати боєприпасів, що може призвести як до жертв серед місцевого населення, так і до руйнації об'єктів інфраструктури. Довготривале ведення вогню по цілі без зміни позиції має ще один негативний момент - виконання вогневої задачі в сучасних бойових умовах може бути небезпечне через наявність у протидіючої сторони засобів артилерійської розвідки: АРЛС типу “Зоопарк”, СНАР-10, АРК-1, звукометричних комплексів типу АЗК-5(7). Зважаючи на це, виникає необхідність у розробленні, прийнятті на озброєння та включенні до складу артилерійських систем сучасних високоточних боєприпасів, що дасть змогу значно підвищити ефективність вогневого ураження противника, зменшити витрату боєприпасів під час стрільби по різноманітним за габаритами цілям та, відповідно, зменшити час виконання вогневого завдання. Це питання потребує проведення відповідних наукових досліджень.

Аналіз останніх досліджень i публікацій. Дослідженнями в цій області 3 відповідними публікаціями наведені у джерелах [1-2, 5, 7-15], де висвітлені питання щодо розробок у сфері систем високоточної зброї, корекції траєкторії літальних апаратів та інтегрування елементів системи космічної радіонавігації у новітні засоби ураження. Проте викладені результати досліджень потребують узагальнення для обгрунтування пропозицій щодо підвищення ефективності застосування артилерійського озброєння. Актуальність цього питання для Збройних Сил України останнім часом значно зросла, враховуючи необхідність ведення бойових дій на Сході України.

Метою статті $\epsilon$ аналіз методів і систем наведення сучасних артилерійських боєприпасів, сучасного стану відповідних розробок передових у військовому відношенні країн світу, що має бути корисним під час розроблення тактико-технічних вимог до сучасних і перспективних систем озброєння.

Виклад основного матеріалу. Сучасний артилерійський високоточний боєприпас - це складна система. У цій роботі під високоточним артилерійським боєприпасом (ВТАБ) розумітимо керуємий (коректуємий) артилерійський снаряд, оснащений системою наведення, яка забезпечує влучення в ціль 3 імовірністю більше 0,5 у межах повної дальності стрільби в будь-який час доби та за будь-якої погоди в умовах протидії противника.

Умова, під час виконання якої система наведення (СН) здійснить наведення ВТАБ на ціль, незалежно від принципу управління та його технічного виконання, називається методом наведення. Метод наведення визначає теоретичну траєкторію ВТАБ. Обраний метод реалізується за допомогою обчислювального приладу, що отримує балістичні дані снаряда. На основі цих даних обчислювальний прилад визначає бажану траєкторію польоту ВТАБ і найвигіднішу точку зустрічі з ціллю. Результат розрахунків перетворюється в керуючі сигнали, які передаються на органи управління.

Залежно від характеру сигналів, що видаються $\mathrm{CH}$, та характеру кінематичних зв'язків, що накладаються на рух центру мас снаряду у разі ідеальної реалізації методів самонаведення, ці алгоритми (методи) доцільно розділити на дві групи: 
метод прямого наведення (пряме паралельне зближення, пропорційне самонаведення, метод погоні); наведення) [1]. Основні методи наведення та їх

метод самонаведення 3 упередженням характеристики наведені на рис. 1.

(наведення 3 постійним кутом упередження,

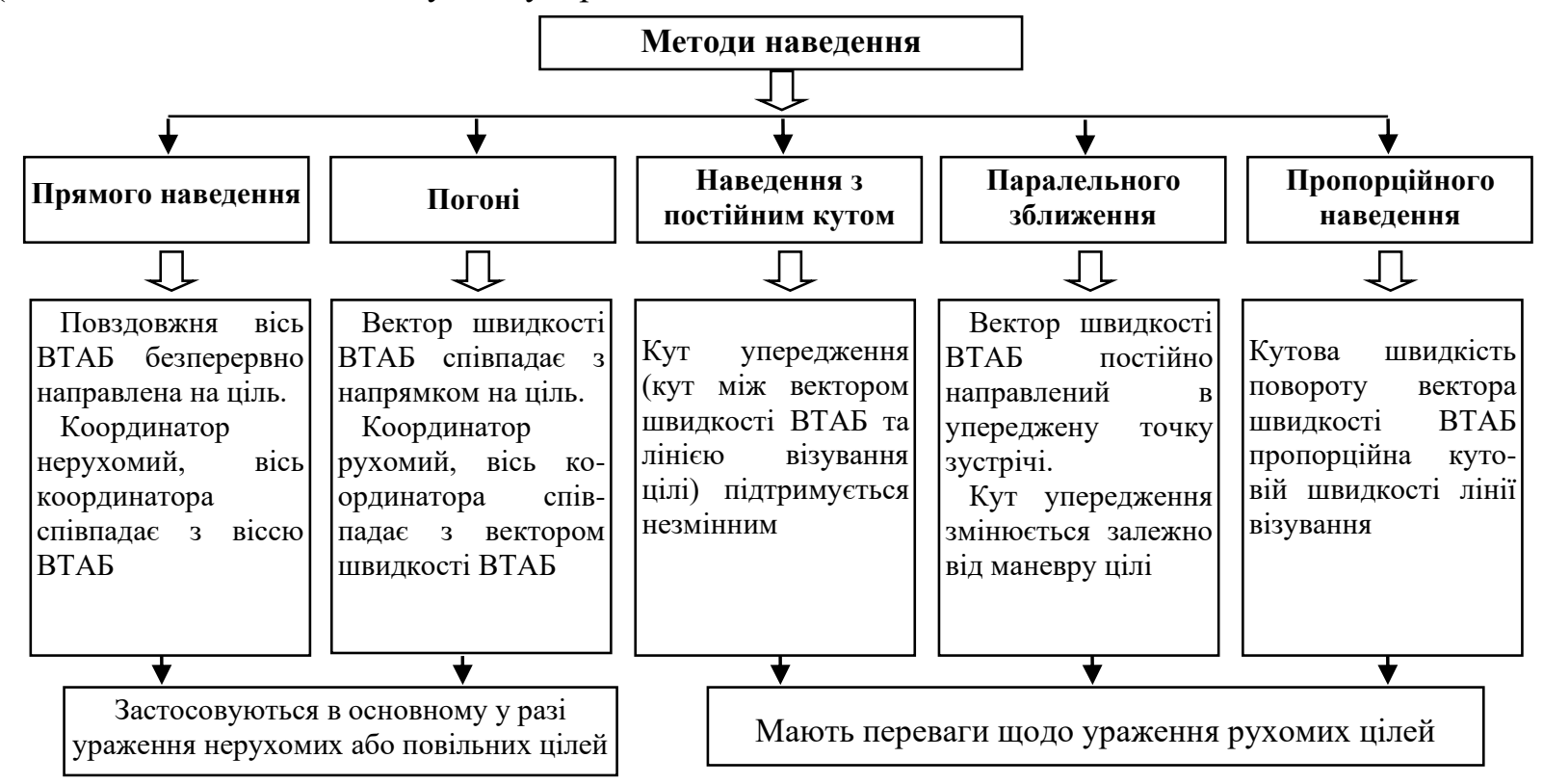

Рис. 1. Класифікація та характеристика методів самонаведення

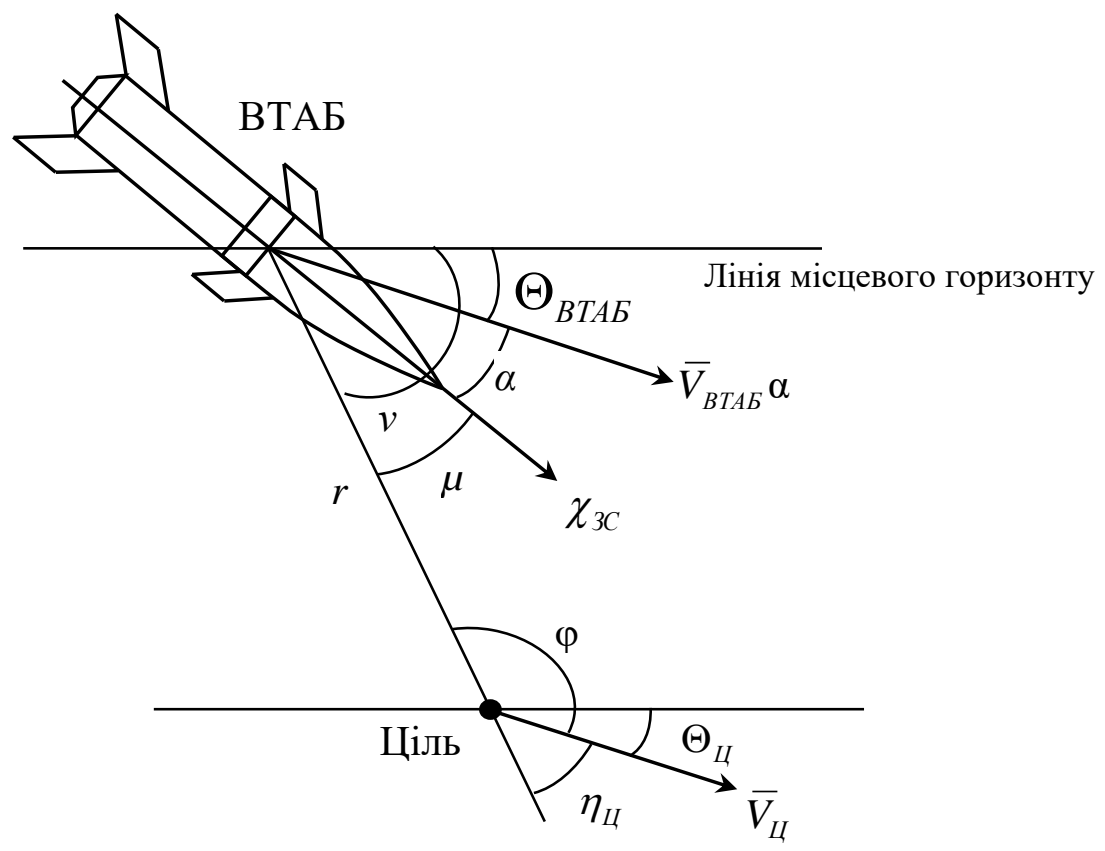

Рис. 2. Кінематичні параметри руху ВТАБ

За кількістю елементів, що визначають кінематику руху ВТАБ, самонаведення $є$ двоточковим методом (під час наведення беруть участь дві точки - ціль та ВТАБ). Основною інформацією, що використовується під час реалізації самонаведення, є дані про параметри відносного руху ВТАБ та цілі [1]. Для розкриття суті методів наведення введемо декілька визначень (рис. 2):

\section{наведення} артилерійського боєприпасу відбувається в площині векторів $\bar{V}_{B T A Б}$ та $\bar{V}_{L}$;

$$
r \text { - лінія "ВТАБ-ціль" - лінія візування }
$$

цілі (відносна дальність між ВТАБ та ціллю);

$$
\alpha \text { - кут атаки; }
$$

$\mu$ - кут пеленга цілі (кут між повздовжньою віссю ВТАБ та лінією візування); 


$$
\Theta_{\text {ВТАБ }}\left(\Theta_{Ц}\right)-\text { кут нахилу вектора }
$$

швидкості ВТАБ (цілі) до лінії горизонту;

$(\alpha+\mu)$ - кут упередження (кут між вектором швидкості ВТАБ та лінією візування);

$$
\left(\alpha+\Theta_{\text {вТАБ }}\right) \text { - кут тангажу (кут між }
$$

лінією горизонту та повздовжньою віссю ВТАБ) [1].

Сутність методу прямого наведення полягає в тому, що повздовжня вісь снаряду $\chi_{3 C}$ безперервно направлена на ціль. Тобто виконується умова, що кут пеленга цілі $\mu=0$. У цьому разі координатор встановлюється на ВТАБ нерухомо, а осі координатора та ВТАБ співпадають. 3 рис. 2 видно, що якщо ціль буде рухомою й змінюватиме свій напрямок,

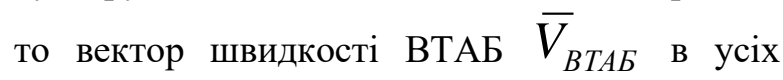
випадках відставатиме від лінії візування на кут $\alpha$, тобто ураження цілі не відбудеться. Отже, метод прямого наведення може бути застосований тільки під час ураження нерухомих цілей або цілей, швидкість яких набагато менша за швидкість ВТАБ [1].

Метод погоні характеризується тим, що вектор швидкості ВТАБ $\bar{V}_{\text {ВтАБ }}$ у кожен момент часу співпадає $з$ напрямком на ціль, тобто кут упередження $(\alpha+\mu)=0$. Отже, для наведення за методом погоні апаратура має постійно вимірювати кути $\alpha$ та $\mu$ і видавати команди на органи управління відповідно до величини та знака кута упередження. Оскільки напрямок на ціль визначається координатором, то для того, щоб ВТАБ весь час летів у напрямку цілі, необхідно вісь координатора сумістити 3 вектором швидкості ВТАБ. Цього можна досягти, якщо координатор розвертати за повітряним потоком. Цьому методу властива досить велика крутизна траєкторії під час стрільби по маневрових цілях, що призводить до істотних поперечних навантажень. Отже його застосовують для наведення на нерухомі або малорухомі цілі [1].

Ефективнішим методом наведення, що підвищує ймовірність ураження цілі, особливо високошвидкісної, вважається метод з постійним кутом упередження. Суть цього методу полягає в тому, що у процесі наведення між лінією візування та вектором швидкості втримується постійний, заздалегідь заданий, кут упередження $(\alpha+\mu)=$ const. Biн задається або за допомогою додаткового повороту антени відносно повздовжньої осі ВТАБ, або введенням у параметр розузгодження додаткового сигналу, пропорційного куту упередження.
Методом паралельного зближення (метод наведення 3 послідовним упередженням) називають метод, за умови якого в будь-який момент часу вектор швидкості ВТАБ направлений в миттєву упереджувальну точку. При цьому методі кут упередження в процесі польоту змінюватиметься залежно від маневру цілі. Для наведення ВТАБ в упереджувальну точку, необхідно за будь-яких маневрів цілі змінювати кут упередження, а, відповідно, обчислювальний пристрій має бути встановлений на ВТАБ. При цьому методі наведення лінія візування переміщується паралельно своєму початковому положенню, не змінюючи напрямку (не обертаючись в просторі).

Метод наведення, за умови якого кутова швидкість обертання вектора швидкості ВТАБ пропорційна кутовій швидкості обертання лінії візування, називають методом пропорціийного зближення, тобто,

$$
\frac{d \Theta_{B T A B}}{d t}=A \frac{d v}{d t},
$$

де $A$ - навігаційна постійна.

Вочевидь, що розглянуті методи погоні, наведення 3 постійним кутом упередження та паралельного зближення $€$ окремими випадками методу пропорційного зближення. Якщо у виразі (1) $A \rightarrow \infty$, то отримаємо $d v / d t=0, v=$ const, що відповідає умові методу паралельного зближення; якщо $A=1$, то $v=\Theta_{\text {ВТАБ }}$, що відповідає методу наведення по кривій погоні.

Усі перераховані методи наведені в табл. 1.

3 аналізу методів наведення випливає, що для системи наведення ВТАБ характерними будуть методи наведення за кривою погоні (ураження нерухомих i малорухомих цілей) i наведення в упереджувальну точку (ураження маневрених цілей). Прикладами реалізації вказаних методів $\epsilon$ артилерійські боєприпаси 3 лазерною напівактивною головкою самонаведення типу "Copperhead", "Краснополь“, вітчизняний 152мм "Квітник“ та "Сантиметр" (метод погоні). Одним із суттєвих недоліків указаних типів боєприпасів, де реалізовані дані методи, є значна вартість як зразка засобу ураження, так i комплексу загалом. Отже, одним iз найперспективніших шляхів розвитку ВТАБ $є$ зменшення вартості зразка за умови збереження точності ураження. 
Таблиця 1

Класифікація методів самонаведення високоточних артилерійських боєприпасів

\begin{tabular}{|l|c|}
\hline \multicolumn{1}{|c|}{ Метод } & Вимоги до кінематичних параметрів \\
\hline Пряме наведення & $\mu=0 ; v=\Theta_{B T A Б}+\alpha$ \\
\hline Наведення за кривою погоні & $v=\Theta_{B T A Б} ;(\alpha+\mu)=0$ \\
\hline Наведення з постійним кутом упередження & $(\alpha+\mu)=$ const \\
\hline Паралельне зближення & $\frac{d \Theta_{B T A 5}}{d t}=A \frac{d v}{d t}$ \\
\hline Пропорційне наведення & \\
\hline
\end{tabular}

На сьогодні закордонні фірми проводять роботи щодо розроблення ВТАБ з комплексними системами наведення, які використовують для корекції траєкторії дані космічної радіонавігаційної системи.

Одним 3 перспективних напрямів підвищення точності попадання звичайних осколково-фугасних боєприпасів (ОФ) під час стрільби на більшу дальність за кордоном вважають корекцію траєкторії снаряда. Концепція створення боєприпасів цього типу включає три напрями:

пристрілювальний снаряд;

3 корекцією траєкторії по дальності;

3 корекцією траєкторії по дальності та напрямку.

У всіх випадках команди управління зміною траєкторії польоту снаряда формуються під час використання сигналів від космічної радіонавігаційної системи (КРНС) NAVSTAR.

Перший напрям. Відділення "MLM" фірми "IAI" (Ізраїль) розробляе компактну систему корекції вогню "Compact Fire Adjustment System“ (CFAS), що використовує спеціальний пристрілювальний снаряд, оснащений приймачем системи GPS i каналом зв'язку для визначення координат снаряда на траєкторії і передачі їх на наземну станцію. На основі методів диференціального GPS (Differential GPS Techniques) наземна станція визначає траєкторію польоту пристрілювального снаряда, порівнює iї 3 розрахунковою траєкторією польоту до цілі і розраховує поправки вертикального i горизонтального кутів прицілювання, які необхідно ввести для стрільби бойовими снарядами.

Другий напрям. Корекція траєкторії передбачає оснащення звичайних артилерійських снарядів, стабілізованих обертанням, “інтелектуальними” підривниками. Цей пристрій об'єднує в собі функції не тільки ініціювання підриву бойової частини, але і корекцію траєкторії польоту снаряда або тільки за дальністю, або і за дальністю й за напрямком [2].

На озброєння Сухопутних військ армії США у 2000-х роках було прийнято ХМ1156 PGK (PROJECTILE GUIDANCE KIT, комплект точного наведення снаряду), який являе собою багатофункціональний підривник, який застосовується в осколково-фугасних снарядах. Цей підривник містить GPS-приймач. Перші версії PGK забезпечували точність влучання в межах 50 м від точки прицілювання на дальностях стрільби до 30 км (рис. 3) [3, 7].

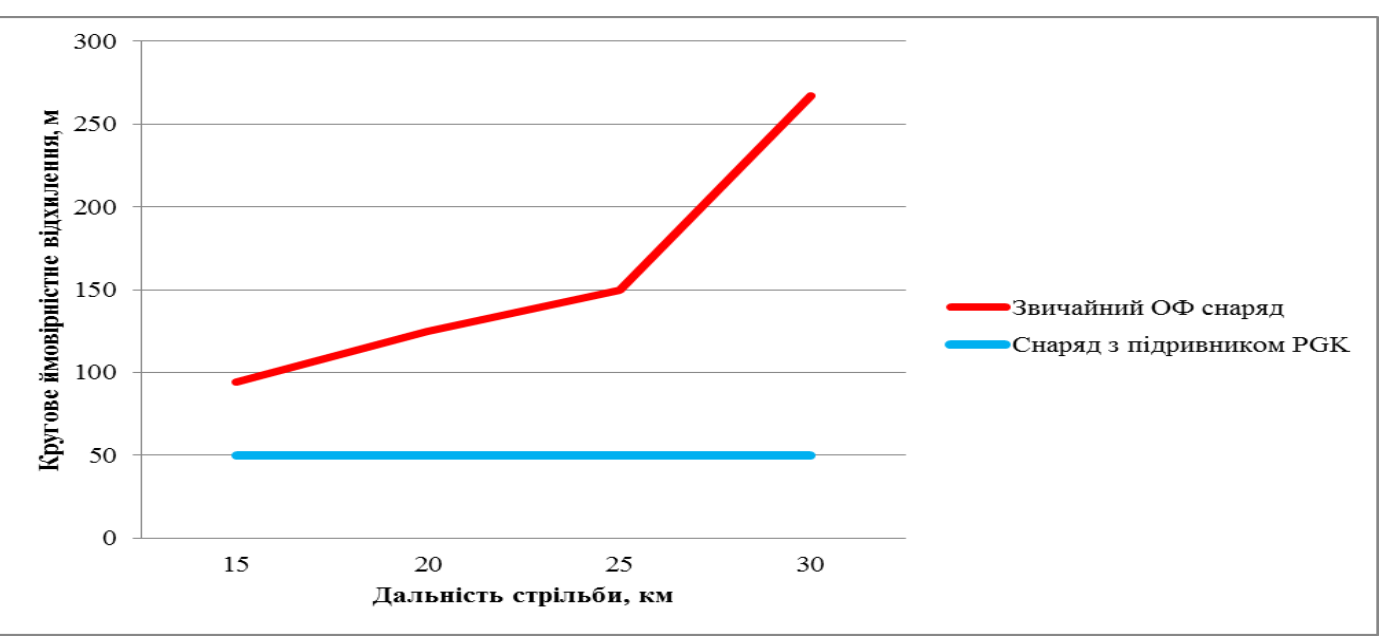




\section{Рис. 3. Порівняльна точність 155-мм снаряда із застосуванням ХМ1156 та звичайних ОФ} снарядів

Усі необхідні дані (координати артилерійської системи та цілі, інформація про траєкторію польоту тощо) вводяться в PGK через кожух за допомогою індуктивного установлювача підривника EPIAFS.

Під час руху система PGK отримує сигнал GPS, обробляє та проводиться наведення. Політ снаряду коригується через уповільнення обертання управляючих рульових поверхонь. За сигналами управління 3 блоку наведення носові рулі обертаються таким чином, щоб орієнтувати вектор підйомної сили та прискорити або уповільнити падіння снаряду.

Якщо промах снаряду складає більше ніж 150 м від точки прицілювання, система PGK автоматично вимикається i снаряд не детонує, що надалі, враховуючи досвід проведення ООС (АТО), значно зменшує втрати цивільного населення та руйнування об'єктів інфраструктури під час ведення стрільби в густонаселеній місцевості.

Перша версія PGK була модернізована та станом на 2012 рік забезпечує точність у 32 м. Найсучасніша версія має точність на рівні 12 м. Надійність PGK складає 94 \%. Крім того, вартість підривника у порівнянні 3 сучасним високоточним снарядом у декілька разів нижча $[3,7]$.

У Великобританії компанія "ВАЕ SYSTEMS“ розробляє комплект наведення "SILVER BULLET" для 155-мм боєприпасів.

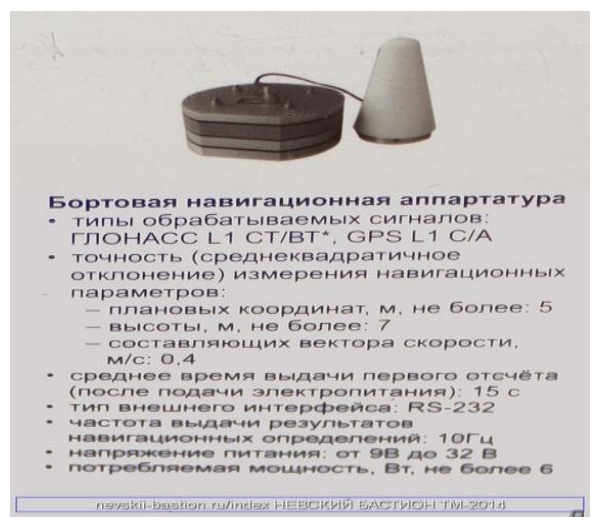

\section{Рис. 5. Виріб БНА-1Д}

Таким чином, системи підвищення ефективності застосування звичайних артилерійських боєприпасів 3'явилися і в РФ. Як і сучасні високоточні боєприпаси типу XM982 EXCALIBUR (CША), сучасний російський боєприпас за допомогою електронних пристроїв може наводитися на ціль за допомогою сигналів супутникової навігаційної системи. Раніше були відомі лише
Він, як і PGK, встановлюється у снаряді на місце підривника (рис. 4).

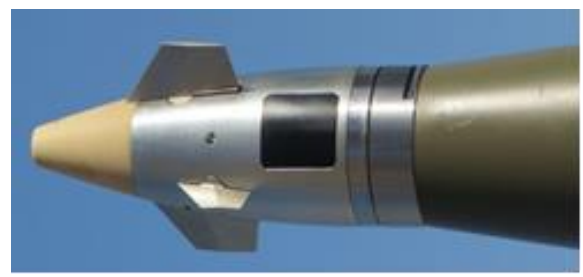

Рис. 4. Комплект наведення "SILVER BULLET"

Заявлене розробником кругове ймовірнісне відхилення комплекту наведення "SILVER BULLET" менше 20 м.

На міжнародному форумі “Технології в машинобудуванні-2014” та міжнародній виставці “ОБОРОНЕКСПО-2014" оборонне підприємство Московське КБ "КОМПАС" (РФ) продемонструвало нову систему наведення для артилерійських боєприпасів, що використовує сигнали супутникової навігаційних систем ГЛОНАCC і GPS - виріб БНА-1Д (рис. 5). Виріб БНА-1Д призначений для вирішення в реальному масштабі часу завдань визначення на борту артилерійського боєприпасу кінематичних параметрів траєкторії. Виріб БНА-1Д забезпечує автоматичне визначення місцеположення, складових вектора швидкості, поточного часу, кількості на борту боєприпасів (артилерійських снарядів, снарядів РСЗВ, артилерійських мін, ракет різного призначення) за сигналами РКНС ГЛОНАСС і GPS.

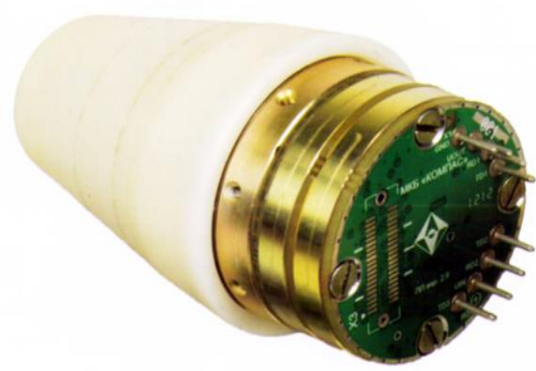

боєприпаси тільки 3 лазерними напівактивними системами наведення типу "Краснополь", "Грань”, “Китолов”, "Сантиметр" i "Смєльчак” [4].

Основні ТТХ виробу БНА-1Д за даними виробника наведено у табл. .2.

Найбільш загальний випадок - корекція тільки по дальності, оскільки під час стрільби на великі дальності саме промах по дальності $\epsilon$ 
найбільшою компонентою загального промаху. Рішення завдання 3 корекції досягається зміною лобового опору завдяки оснащенню підривника зі змінною геометрією аеродинамічних гальм, що розкриваються в польоті. Це призводить до конструктивного ускладнення пристрою і підвищенню вартості підривника, але кінцевим результатом цього рішення $\epsilon$ зростання ефективності ураження цілі, зменшення витрати боєприпасів і скорочення супутніх руйнувань.

\begin{tabular}{|l|c|}
\hline \multicolumn{1}{|c|}{ Характеристика } & Величина \\
\hline Сигнали діапазону L1, що обробляються & ГЛОНАСС/ GPS \\
\hline Номера літер частот ГЛОНАСС, що обробляються & $-7 . .+6$ \\
\hline Кількість каналів обробки & 48 \\
\hline $\begin{array}{l}\text { Середньоквадратичне відхилення похибки визначення координат: } \\
\text { у горизонтальній площині (X,Z) не більше, м; } \\
\text { у вертикальній плещині (Y) не більше, м }\end{array}$ & 6,0 \\
\hline Середньоквадратичне відхилення похибки визначення складових вектора & 8,0 \\
\hline швидкості, не більше, м/с & 0,1 \\
\hline Час видачі першого відліку навігаційних параметрів: & 18 \\
при “гарячому старті”, не більше, сек & 45 \\
при “холодному старті”, не більше, сек & 10 \\
\hline Частота видачі результатів виміру, Гц & $8,0 \ldots .15,5$ \\
\hline Напруга живлення, В & 2,2 \\
\hline Максимальна потужність споживання, Вт & RS-232 \\
\hline Інтерфейс & 0,155 \\
\hline Маса, кг & \\
\hline
\end{tabular}

\section{$\begin{array}{rc}\text { Прикладами } & \text { можуть бути розробки } \\ \text { фірми "GIAT" } & \text { (Франція) - детонатор }\end{array}$} "SPACIDO” (рис. 6), що приймає сигнали на розкриття балістичного гальма не від GPS, а від наземної станції.

Принцип дії снаряда із системою корекції траєкторії польоту “SPACIDO” складається у порівнянні реальної траєкторії із запланованою. Усі вбудовані компоненти пристрою корекції траєкторії розміщуються у внутрішньому просторі головного підривника. Таким чином, система сумісна 3 усіма 155-мм боєприпасами як тими, що вже перебувають на озброєнні, так і знаходяться на стадії розроблення. Очікуване збільшення точності дасть змогу підвищити коефіцієнт ефективності стрільби на значні дальності в чотири рази $[1,2]$.

\section{Рис. 6. Підривник, оснащений системою корекції траєкторії "SPACIDO"}

На паризькій виставці “EUROSATORY2010" ізраїльська компанія "ISRAEL AEROSPACE INDUSTRIES (IAI)" представила своє рішення щодо підвищення точності влучання боєприпасів - “TOPGUN” (рис. 7). Це підривник із функціями навігації й коригування, який можна встановлювати в усі звичайні 155-мм снаряди. Як повідомляється, снаряди із системою "TOPGUN" мають максимальне кругове ймовірнісне відхилення усього 20 м на дальності до 40 км. Крім того, компанія "ISRAEL MILITARY INDUSTRIES (IMI)" поставляє GM81 - це 81-мм керований за GPS сигналом мінометний снаряд для сухопутних військ із круговим ймовірнісним відхиленням менш $10 \mathrm{~m}$.

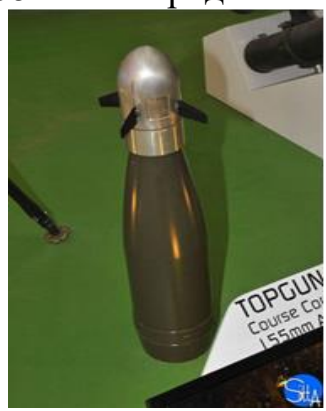

Рис. 7

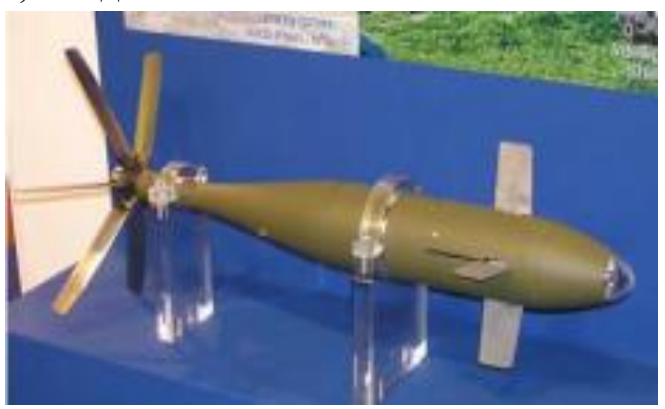

Рис. 8 
Також, цією фірмою розроблено керовану 120-мм міну "FIREBALL" LGMB 3 дальністю стрільби до 15 км (рис. 8). Вона оснащена лазерною головкою самонаведення і GPS приймачем. Бойова частина багатофункціональна, 3 різною установкою підривника: на осколкову дію по найбільш вразливих цілям; ударне - по броньованим i проникаюче - по бункерах і цілях всередині будівель. Кругове ймовірнісне відхилення, згідно 3 даними розробників, становить $1 \mathrm{~m} \mathrm{i}$ менше під час стрільби по стаціонарних і рухомих цілях.

Ізраїльський 120-мм керований мінометний снаряд, відомий як "PURE HEART" - результат співробітництва компаній "IMI" i "RAYTHEON". Боєприпаси оснащуються наведенням по GPS та технологією лазерного наведення. "IMI" займається GPS наведенням, a "RAYTHEON" надає компоненти лазерного наведення. Заявлена дійсна дальність снаряда становить 13 км. У процесі роботи снаряда в режимі тільки наведення по GPS, максимальне кругове ймовірнісне відхилення становить менш 10 метрів. У разі додавання лазерного наведення точність може бути збільшена і складе менш $1,5 \mathrm{м}[5]$.

На сьогодні створення снарядів збільшеної дальності, які використовують для корекції траєкторії дані KPHC NAVSTAR, вже дає змогу польовій артилерії успішно вирішувати завдання 3 високоточного вогневого ураження як групових, так $\mathrm{i}$ одиночних неспостережних цілей в будь-яких метеорологічних умовах за відносно невеликому розході боєприпасів.

Третій напрям. Корекція траєкторії по дальності і напрямку, що здійснюється завдяки конструктивному рішенню оснащенням підривника стабілізованими по крену (горизонтальними) рулями призводить до значного дорожчання снаряда [2].

Таким чином, аналіз сучасного стану та тенденцій розвитку високоточних артилерійських боєприпасів дає змогу дійти висновку, що у провідних країнах світу проводяться широкомасштабні роботи зі створення високоточних артилерійських боєприпасів. Кооперація й інтеграція між фірмами та державами, залучення кваліфікованих кадрів і необхідне фінансування дали змогу в порівняно короткі терміни досягти значних успіхів щодо їх розроблення.
Враховуючи всі сучасні загрози, назріла нагальна необхідність впровадження $\mathrm{y}$ вітчизняні артилерійські комплекси високоточної зброї, спираючись на останні досягнення мікроелектронної техніки та технології створення високоточних боєприпасів останніх поколінь, що реалізують принцип "вистрілив-забув-вразив" із застосуванням супутникової навігації.

3 огляду на наведене, в Україні доцільно обрати шлях створення ВТАБ з комбінованою системою наведення та "інтелектуальних" підривників на вже існуючі засоби ураження.

Подальші дослідження доцільно зосередити на застосуванні сигналу супутників радіонавігаційних космічних систем у системах високоточної зброї.

\section{СПИСОК ВИКОРИСТАНОЇ ЛІТЕРАПТУРИ}

1. В. А. Чубасов, Е. И. Стрюков, И. А. Алексеев, А. И. Волков // Высокоточные боеприпасы // Санкт-Петербург, 2008.

2. В. И. Запорожец, В. Ф. Руссков, С. Д. Ладный, В.И. Иванов Высокоточные боеприпасы // Основы устройства и проектирования // Институт систем вооружения, Санкт-Петербург, 2008.

3. http://www.strategypage.com/htmw/htart/articles/20 140730.aspx/Artillery: Accuracy And Reliability Beat Price.

4. Управляемые снаряды с системой навигации ГЛОНАСС http://nevskii-bastion.ru/us-glonass/ ВТС Невский Бастион А. V. Karpenko.

5. В. Мерзляков. Артиллерийские боеприпасы следующего поколения, 26.12.2012 р. // info@army-guide.com.

6. П. А. Щетинин // Теоретические основы стрельбы на подавление //, Военная ордена Ленина и ордена Суворова Артиллерийская инженерная академия им. Ф. Э. Дзержинского // Москва, 1956. С. 13-81.

7. XM1156 Precision Guidance Kit (PGK) Overviewfor 2010 Fuze Conference12-13 May 2010 // Peter J. Burke, Deputy Product Manager, Mortar Systems; Anthony Pergolizzi, Army Fuze Management Office.

8. І. В. Науменко, В. Ю. Косухін. Аналіз методів наведення високоточних артилерійських та ракетних боєприпасів // Системи обробки інформації, № 1. 2004. С. 160-163.

9. М. Л. Клочко, С. В. Лапицький, Б. О. Оліярник, П. П. Ткачук. Сучасні комплекси керованого артилерійського озброєння як елемент ведення розвідувально-вогневих дій тактичного рівня.

10. К. А. Неусипин, Д. О. Шолохов, К. Фан. Разработки алгоритма построения моделей с помощью метода самоорганизации для коррекции навигационных систем // Вісник МГТУ ім. Н. Е. Баумана. Приладобудування, 2010.№ 3. C. 57-67. 
11. А. В. Пролетарський, К. А. Нєусипін, К. Шень Исследование алгоритмов коррекции навигационных систем летательных аппаратов // Вісник МГТУ ім. Н. Е. Баумана. “Приладобудування”. 2016. № 2. С. 28-39.

12. Д. Д. Малинин, А. Є. Шаралапов. Повышение точности позиционирования мобильной платформы путем коррекции GPS сигнала фильтром Калмана, 2014рік / Д. Д. Малинин, А. Е. Шаралапов // Надежность и качество сложных систем. 2014. № 3 (7). С. 44-49.

13. П. В. Васильев, А. В. Мелешко, В. В. Пятаков. Повышение точности корректируемой инерциальной навигационной системы, Приладобудування. 2014. Т. 57, № 12.

14. А. К. Синякин, А. В. Кошелев. Вопросы корреляционной обработки GPS-сигналов // 2005 , СГГА, Новосибирськ.

15. А. В. Чорнодаров, А. П. Патрикеев, I. I. Меркулова, С. А. Иванов. Комплексирование распределенных инерциальных навигационных систем на базе волоконно-оптических и МЭМ измерителей // Научный Вестник МГТУ ГА // Том 20, № 06, 2017. С. 111-120.

Стаття надійшла до редакційної колегії 01.03.2019

\section{Дорофеев Н. В. ${ }^{1}$;}

Семененко В. М., к.т.н., с.н.с. ${ }^{2}$

1 - Центральный научно-исследовательский институт вооружения и военной техники Вооруженных Сил Украины, Киев;

2 - Центр военно-стратегических исследований Национального университета оборони Украины имени Ивана Черняховского, Киев

\section{Анализ методов и систем наведения современных артиллерийских боеприпасов}

Резюме. Проведен анализ методов и систем наведения современных высокоточных артиллерийских боеприпасов и варианты их реализации в артиллерийских системах передовых в военном отношении армий мира.

Ключевые слова: методы наведения; артиллерийские снаряды; GPS; радионавигационные космические системы.

\section{N. Dorofeev ${ }^{1}$;}

V. Semenenko, PhD (Technical), assistant professor ${ }^{2}$

1 - Central Research Institute of weapons and military equipment of the Armed Forces of Ukraine, Kiev;

${ }^{2-}$ Center for Military and Strategic Studies of the National Defence University of Ukraine named after Ivan Cherniakhovskyi, Kyiv

\section{Analysis of methods and guidance systems of modern artillery ammunition}

Resume. The article discusses the main issues of analyzing methods and guidance systems of modern highprecision artillery ammunition, characteristics and options for the implementation in the world's most advanced military armies, in artillery systems.

Keywords: guidance methods, artillery shells, GPS; radio navigation space systems. 